\title{
A RESISTANCE TEST OF OIL PALM VARIETIES (ELAEIS GUINEENSIS JACQ.) IN THE SALINE SOIL WITH AN ADDUCTION OF HUMIC ACID
}

\author{
Hari Gunawan $^{1 *}$ Rosmayati $^{2}$, T. Sabrina ${ }^{2}$ \\ ${ }^{1}$ Post graduate of Agrotechnology, Agriculture Faculty, University of North Sumatera, Medan, Indonesia \\ ${ }^{2}$ Agrotechnology Department, Agriculture Faculty, University of North Sumatera, Medan, Indonesia \\ *Corresponding Author: hargunaja@gmail.com
}

\begin{abstract}
The objective of the research was to determine the oil palm variety with saline resistance and identify the effective humic acid application dosage with a different salinity rate. This research was conducted in Percut Village. The method used was Randomized Block Design Factorial with 3 factors applied in to 6 varieties oil palm, humic acid dosage (3 dosages) and salinity rate (3 rate) with 3 replications. The results of this research showed that the salinity rate affected significantly to oil palm morphology in saline soil with humic acid adduction. In $S_{0}(0$ mmhos $)$, Yangambi variety can increase oil palm plant height, number of leaves, root volume and dry weight of roots.
\end{abstract}

Keywords : Humic Acid, Oil Palm, Saline, Variety

\section{INTRODUCTION}

Oil palm is very important for Indonesia during the last 20 years. Palm oil is an important export commodity that can improve the welfare of the farmers' farmers and also increase the deviation (Pardamean, 2008). Until 2014, the highest growth trend of the highest area is reached by oil palm commodities above 6\%, mainly private plantation companies investing for oil palm plantation. Coastal land is one of agricultural extensification in terms of land expansion. The length of the coastline in Indonesia is $106,000 \mathrm{~km}$ with a potential land area of 1,060,000 ha (Directorate General of Estate Crops, 2015).

Decreasing number of land that can be used as agricultural land encourages agricultural cultivation on marginal land such as saline land. The saline soil has a level of neutral salt dissolved in groundwater so it can interfere with the growth of most plants and cause the low level of soil fertility. The saline soil is one of the largely untapped land for cultivation, due to toxic effects and increased root osmotic pressure resulting in disruption of plant growth (Slinger $\&$ Tenison, 2005).

Salt stress occurs with the presence of salinity or the concentration of excessive salts in the plant. This salt stress generally occurs in plants on saline soil. The salt stress increases with increasing salt concentration up to a certain concentration level that can lead to crop death (Harjadi \& Yahya, 1988).

Humic acid is a complex molecule that consists of a collection of various organic materials derived from residuals from plant and animal decomposition. Most humic acid is derived from the extraction of leonardite or lignite material (Tan, 2000). The growth of three-month-old cocoa seedlings with either NPK fertilizer treatment or its combination with humic acid showed an increase in the response to humic acid administration of $7.5 \mathrm{ml}$ (Santi, 2015). Humic acid promotes the growth of tomato plants through nutrient degradation to overcome nutritional deficiencies and can promote growth and production. Many researchers who use humic acid to increase plant growth and productivity have been a major concern in recent decades, but the application of humic acid to saline soils with oil palm plantations has not been studied (Abdel et al., 2007).

Based on the above description, the authors conducted a study on "A Resistance Test of Oil Palm Varieties (Elaeis guineensis Jacq.) in the Saline Soil with an Adduction of Humic Acid". The objective of this study was to determine the effect of resistance and growth of some oil palm varieties on saline fields with different salinity levels, to determine the effect of humic acid administration on growth of oil palm at different salinity levels and knowing the influence of several varieties, giving humic acid and soil salinity level to changes in plant morphology.

\section{MATERIALS AND METHOD}

This research was conducted in Percut Village on January-June 2016. This research used Randomized Block Design Factorial with 2 factors and 3 replications. The first factor was varieties of oil palm (V) consists of 6 varieties: Simalungun, Yangambi, Dumpy, PPKS 540, Langkat and PPKS 239. The second factor was salinity level (S) 
consists of 3 level: control, 5-6 mmhos/cm and 6-7 mmhos $/ \mathrm{cm}$. The third factor was humic acid (A) dosage level consists of 3 level: $0 \mathrm{~g} /$ polybag / 1 liter of water, $2.5 \mathrm{~g} /$ polybag / 1 liter water and $5 \mathrm{~g} / \mathrm{polybag} / 1$ liter of water.

The method of humic acid application was by dissolving the dose of humic acid according to the treatment of 1 liter of water / polybag. Time of humic acid application as much as 4 times with interval time 1 month once in the morning. Parameters observed were plant height $(\mathrm{cm})$, number of leaves (strands), root dry weight $(\mathrm{g})$ and root volume (ml). The data were analyzed statistically using F-test and then following by Duncan Multiple Range Test at $5 \%$ level.

\section{RESULTS AND DISCUSS}

\subsection{Plant height $(\mathrm{cm})$}

The result of $\mathrm{F}$ test showed that the treatment of varieties; salinity levels; interaction of varieties and humic acid; the interaction of varieties and salinity levels had a very significant effect on plant height at 15 MST. While the interaction of varieties, salinity and humic acid had significant effect on plant height at 15 MST. Different test of plant height and height of some palm varieties with addition of humic acid and salinity level at 15 MST can be seen in Table 1 .

Table 1. Plant Height (cm) Several Palm Oil Varieties with Addition of Humic Acid and Salinity Content At 15 MST

\begin{tabular}{|c|c|c|c|c|c|c|c|c|}
\hline \multirow{2}{*}{ Treatment } & \multicolumn{6}{|c|}{ Humic Acid } & \multirow{2}{*}{\multicolumn{2}{|c|}{ Average }} \\
\hline & \multicolumn{2}{|c|}{$A_{0}(0 g)$} & \multicolumn{2}{|c|}{$A_{l}(2.5 \mathrm{~g})$} & \multicolumn{2}{|c|}{$A_{2}(5 g)$} & & \\
\hline Variety & & & & & 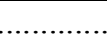 & 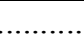 & ............. & \\
\hline $\mathrm{V}_{1}$ (Simalungun) & 36.57 & ef & 37.31 & $c-f$ & 36.20 & ef & 36.69 & $\mathrm{c}$ \\
\hline $\mathrm{V}_{2}($ Yangambi) & 40.29 & $a-d$ & 43.46 & $\mathrm{a}$ & 41.40 & $\mathrm{ab}$ & 41.71 & $\mathrm{a}$ \\
\hline $\mathrm{V}_{3}$ (Dumpy) & 35.80 & ef & 37.99 & $b-f$ & 34.12 & $\mathrm{f}$ & 35.97 & $\mathrm{c}$ \\
\hline $\mathrm{V}_{4}(\mathrm{PPKS} 540)$ & 40.64 & $a-c$ & 37.33 & $c-f$ & 38.78 & b-e & 38.91 & $\mathrm{~b}$ \\
\hline $\mathrm{V}_{5}$ (Langkat) & 36.78 & $d-f$ & 37.61 & $c-f$ & 38.87 & $b-e$ & 37.76 & $\mathrm{bc}$ \\
\hline $\mathrm{V}_{6}(\mathrm{PPKS} 239)$ & 37.12 & $c-f$ & 35.91 & ef & 36.70 & $d-f$ & 36.58 & $\mathrm{c}$ \\
\hline \multicolumn{9}{|l|}{ Salinity } \\
\hline $\mathrm{S}_{0}(0 \mathrm{mmhos})$ & 44.02 & & 43.57 & & 44.29 & & 43.96 & $\mathrm{a}$ \\
\hline $\mathrm{S}_{1}(5-6 \mathrm{mmhos})$ & 35.11 & & 36.41 & & 34.90 & & 35.47 & $\mathrm{~b}$ \\
\hline $\mathrm{S}_{2}(6-7 \mathrm{mmhos})$ & 34.47 & & 34.83 & & 33.84 & & 34.38 & $\mathrm{~b}$ \\
\hline \multicolumn{9}{|l|}{ Interaction $\mathrm{VxSxA}$} \\
\hline $\mathrm{V}_{1} \mathrm{~S}_{0}$ & 42.24 & $b-1$ & 45.33 & b-g & 45.32 & b-h & 44.30 & $\mathrm{bc}$ \\
\hline $\mathrm{V}_{1} \mathrm{~S}_{1}$ & 37.31 & j-s & 33.76 & $n-u$ & 34.30 & $\mathrm{~m}-\mathrm{u}$ & 35.12 & e-g \\
\hline $\mathrm{V}_{1} \mathrm{~S}_{2}$ & 30.14 & tu & 32.84 & $\mathrm{n}-\mathrm{u}$ & 28.98 & $\mathrm{u}$ & 30.66 & $\mathrm{~h}$ \\
\hline $\mathrm{V}_{2} \mathrm{~S}_{0}$ & 48.16 & $\mathrm{ab}$ & 52.50 & $\mathrm{a}$ & 46.11 & b-e & 48.92 & $\mathrm{a}$ \\
\hline $\mathrm{V}_{2} \mathrm{~S}_{1}$ & 35.60 & $1-\mathrm{u}$ & 39.23 & $f-p$ & 39.59 & e-o & 38.14 & ef \\
\hline $\mathrm{V}_{2} \mathrm{~S}_{2}$ & 37.11 & $\mathrm{j}-\mathrm{t}$ & 38.63 & g-q & 38.49 & $h-q$ & 38.08 & ef \\
\hline $\mathrm{V}_{3} \mathrm{~S}_{0}$ & 39.72 & d-n & 40.93 & $\mathrm{c}-\mathrm{m}$ & 36.07 & $1-u$ & 38.91 & de \\
\hline $\mathrm{V}_{3} \mathrm{~S}_{1}$ & 32.57 & $\mathrm{o}-\mathrm{u}$ & 35.62 & $1-u$ & 32.22 & $\mathrm{p}-\mathrm{u}$ & 33.47 & $\mathrm{gh}$ \\
\hline $\mathrm{V}_{3} \mathrm{~S}_{2}$ & 35.12 & $\mathrm{~m}-\mathrm{u}$ & 37.41 & $\mathrm{j}-\mathrm{s}$ & 34.07 & $\mathrm{~m}-\mathrm{u}$ & 35.53 & e-g \\
\hline $\mathrm{V}_{4} \mathrm{~S}_{0}$ & 45.52 & $b-f$ & 46.24 & b-d & 46.80 & $a-c$ & 46.19 & $a b$ \\
\hline $\mathrm{V}_{4} \mathrm{~S}_{1}$ & 39.61 & e-o & 35.15 & $\mathrm{~m}-\mathrm{u}$ & 33.78 & $n-u$ & 36.18 & e-g \\
\hline $\mathrm{V}_{4} \mathrm{~S}_{2}$ & 36.79 & $\mathrm{k}-\mathrm{t}$ & 30.59 & $\mathrm{~s}-\mathrm{u}$ & 35.75 & $1-u$ & 34.38 & $f-h$ \\
\hline $\mathrm{V}_{5} \mathrm{~S}_{0}$ & 44.49 & $b-i$ & 37.83 & i-r & 48.10 & $\mathrm{ab}$ & 43.47 & $\mathrm{bc}$ \\
\hline $\mathrm{V}_{5} \mathrm{~S}_{1}$ & 33.78 & $\mathrm{n}-\mathrm{u}$ & 37.83 & i-r & 34.08 & $\mathrm{~m}-\mathrm{u}$ & 35.23 & e-g \\
\hline $\mathrm{V}_{5} \mathrm{~S}_{2}$ & 32.09 & $q-u$ & 37.17 & $j-t$ & 34.43 & $\mathrm{~m}-\mathrm{u}$ & 34.56 & f-h \\
\hline $\mathrm{V}_{6} \mathrm{~S}_{0}$ & 44.00 & $b-j$ & 38.56 & g-q & 43.34 & b-k & 41.97 & $\mathrm{~cd}$ \\
\hline $\mathrm{V}_{6} \mathrm{~S}_{1}$ & 31.80 & $q-u$ & 36.84 & $\mathrm{k}-\mathrm{t}$ & 35.42 & $1-\mathrm{u}$ & 34.69 & $f-h$ \\
\hline $\mathrm{V}_{6} \mathrm{~S}_{2}$ & 35.56 & $1-\mathrm{u}$ & 32.32 & $\mathrm{p}-\mathrm{u}$ & 31.34 & $\mathrm{r}-\mathrm{u}$ & 33.08 & $\mathrm{gh}$ \\
\hline Average & 37.87 & & 38.27 & & 37.68 & & & \\
\hline
\end{tabular}

Note: The numbers followed by the same letter on the same row or column is not different significant according to Duncan Multiple Range Test at 5\% level. 
The highest yield of plant height was obtained at the treatment of $\mathrm{V}_{2} \mathrm{~S}_{0} \mathrm{~A}_{1}$ (Yangambi + non saline soil $+2.5 \mathrm{~g}$ humic acid) that is $52,50 \mathrm{~cm}$, while the lowest in treatment of $\mathrm{V}_{1} \mathrm{~S}_{2} \mathrm{~A}_{2}$ (Simalungun $+5 \mathrm{~g}$ humic acid + saline soil 6-7 mmhos) that is $28.98 \mathrm{~cm}$. This indicates that each of the oil palm varieties in this study has not been able to adapt to grow on high saline soil conditions. Each variety shows that the genetic variation factor of each variety, which has a different genetic makeup follows its parent nature, so that the height of the plant is different. Genetic variation is caused by genetic inheritance and environmental factors (Welsh, 1981).

The result of observation of intervariety on Simalungun variety can be seen that the highest plant height parameters in the combination of treatment $\mathrm{V}_{1} \mathrm{~S}_{0} \mathrm{~A}_{1}$ and lowest $\mathrm{V}_{1} \mathrm{~S}_{2} \mathrm{~A}_{2}$. Yangambi variety yields the highest yield on the combination of $\mathrm{V}_{2} \mathrm{~S}_{0} \mathrm{~A}_{1}$ and the lowest on $\mathrm{V}_{2} \mathrm{~S}_{1} \mathrm{~A}_{0}$. Dumpy variety was the highest yield on the combination of $V_{3} S_{0} A_{1}$ and lowest treatment was obtained on $V_{3} S_{1} A_{2}$. PPKS 540 variety yield the highest combination of $V_{4} S_{0} A_{2}$ treatment and the lowest on $\mathrm{V}_{4} \mathrm{~S}_{2} \mathrm{~A}_{1}$. Langkat variety for the highest yield of the highest plant on the combination of $\mathrm{V}_{5} \mathrm{~S}_{0} \mathrm{~A}_{2}$ and the lowest obtained in combination $\mathrm{V}_{5} \mathrm{~S}_{1} \mathrm{~A}_{0}$. While for the highest PPKS 239 yield on the combination of $\mathrm{V}_{6} \mathrm{~S}_{0} \mathrm{~A}_{0}$ treatment and the lowest on the combination of $\mathrm{V}_{6} \mathrm{~S}_{2} \mathrm{~A}_{2}$.

The highest plant height at the 5-6 mmhos salinity level was found in $\mathrm{V}_{4} \mathrm{~S}_{1} \mathrm{~A}_{0}$ (PPKS 540 + 5-6 mmhos $+0 \mathrm{~g}$ humic acid) of $39.61 \mathrm{~cm}$ and the lowest on $\mathrm{V}_{6} \mathrm{~S}_{1} \mathrm{~A}_{1}$ (PPKS $239+5-6$ mmhos $+2.5 \mathrm{~g}$ humic acid) is $31.80 \mathrm{~cm}$. While the highest plant height at the salinity level of 6-7 mmhos is found in $\mathrm{V}_{2} \mathrm{~S}_{2} \mathrm{~A}_{1}$ (Yangambi $+6-7$ mmhos $+2.5 \mathrm{~g}$ humic acid) which is $38.63 \mathrm{~cm}$ and the lowest in $\mathrm{V}_{4} \mathrm{~S}_{2} \mathrm{~A}_{1}$ (PPKS $540+6-7$ mmhos $+2,5 \mathrm{~g}$ humic acid) is $30.59 \mathrm{~cm}$. At 5-6 mmhos salinity level, the best variety is PPKS 540 while in 6-7 mmhos is Yangambi. The difference in these results indicates that each plant variety has different responses to its environmental conditions. Differences in genetic makeup is one of the factors causing plant appearance diversity. The genetic program to be expressed in a different growth phase can be expressed on a variety of plant traits that include the shape and function of plants that produce plant growth diversity. The diversity of plant appearance due to differences in genetic makeup is always and may occur even if the plants used are of the same kind (Sitompul \& Guritno, 1995).

At salinity level 5-6 mmhos best humic acid is $0 \mathrm{~g}$ humic acid, while at salinity level 6-7 mmhos best humic acid is $2.5 \mathrm{~g}$ humic acid. The low dose of humic acid given suggests that the plant responds better to a lower dose of humic acid. The use of humic acid with high concentration can interfere with plant growth. The main effect of salinity is the decrease in leaf growth that directly leads to reduced plant photosynthesis. Salinity reduces growth and crop yields are important and in the worst conditions can lead to crop failure. In saline conditions, growth and development of plants are inhibited due to excessive accumulation of $\mathrm{Na}$ and $\mathrm{Cl}$ in the cytoplasm, causing changes in metabolism in cells (Lestari, 2006) (Yuniati, 2014).

\subsection{Number of leaves (strands)}

The result of F-test showed that the treatment of varieties, salinity levels, interaction of varieties and salinity levels as well as interaction of varieties, humic acid dose and salinity levels significantly affected the number of leaves at 15 MST. The interaction of varieties and humic acid and the interaction of salinity and humic acid had significant effect on leaf count at 15 MST. Different difference test and number of leaves of several varieties of oil palm with addition of humic acid and salinity level at 15 MST can be seen in Table 2.

Provision of humic acid in saline medium to varieties increases the number of leaves at a dose of $2.5 \mathrm{~g}$ of humic acid. The highest number of leaflets was obtained in the $\mathrm{V}_{2} \mathrm{~A}_{1} \mathrm{~S}_{0}$ treatment of 12.44 strands which was not statistically significantly different from the treatment of $\mathrm{V}_{2} \mathrm{~S}_{0} \mathrm{~A}_{0}, \mathrm{~V}_{4} \mathrm{~S}_{0} \mathrm{~A}_{0}, \mathrm{~V}_{5} \mathrm{~S}_{0} \mathrm{~A}_{0}, \mathrm{~V}_{2} \mathrm{~S}_{0} \mathrm{~A}_{2}, \mathrm{~V}_{5} \mathrm{~S}_{0} \mathrm{~A}_{2}, \mathrm{~V}_{3} \mathrm{~S}_{0} \mathrm{~A}_{0}$ and $\mathrm{V}_{4} \mathrm{~S}_{0} \mathrm{~A}_{1}$.

The interaction of observation of Simalungun (V1) highest number of leaves on combination of $V_{1} S_{0} A_{1}$ is 12,44 strands and the lowest in combination of $\mathrm{V}_{1} \mathrm{~S}_{2} \mathrm{~A}_{2}$ is 7.33 strands. Yangambi combination of the highest $\mathrm{V}_{2} \mathrm{~S}_{0} \mathrm{~A}_{1}$ treatment compared to the combination of $\mathrm{V}_{2} \mathrm{~S}_{1} \mathrm{~A}_{1}$. Dumpy on the highest yield leaf parameter in combination of $\mathrm{V}_{3} \mathrm{~S}_{0} \mathrm{~A}_{0}$ and lowest $\mathrm{V}_{2} \mathrm{~S}_{1} \mathrm{~A}_{2}$. PPKS 540 yields the highest for the number of leaves on the combination of $\mathrm{V}_{4} \mathrm{~S}_{0} \mathrm{~A}_{0}$ and the lowest on the combination of $\mathrm{V}_{4} \mathrm{~S}_{2} \mathrm{~A}_{1}$. On Langkat the highest yield of $\mathrm{V}_{5} \mathrm{~S}_{0} \mathrm{~A}_{0}, \mathrm{~V}_{5} \mathrm{~S}_{0} \mathrm{~A}_{2}$ and lowest yield of $\mathrm{V}_{5} \mathrm{~S}_{1} \mathrm{~A}_{0}$. While the PPKS 239 yield the highest number of leaves on the combination of $\mathrm{V}_{6} \mathrm{~S}_{0} \mathrm{~A}_{1}$ and the lowest $\mathrm{V}_{6} \mathrm{~S}_{1} \mathrm{~A}_{0}$.

Observation between varieties performed on leaf number parameters can be seen that the interaction of varieties, salinity, and humic acid for the highest yield of $\mathrm{V}_{2} \mathrm{~S}_{0} \mathrm{~A}_{1}(12,44$ strands), while the lowest in the combination of $\mathrm{V}_{1} \mathrm{~S}_{1} \mathrm{~A}_{2}$ treatment (7.33 strands). 
Table 2. Number of Leaves (strands) Varieties of Oil Palm with Addition of Humic Acid and Salinity Levels at 15 MST

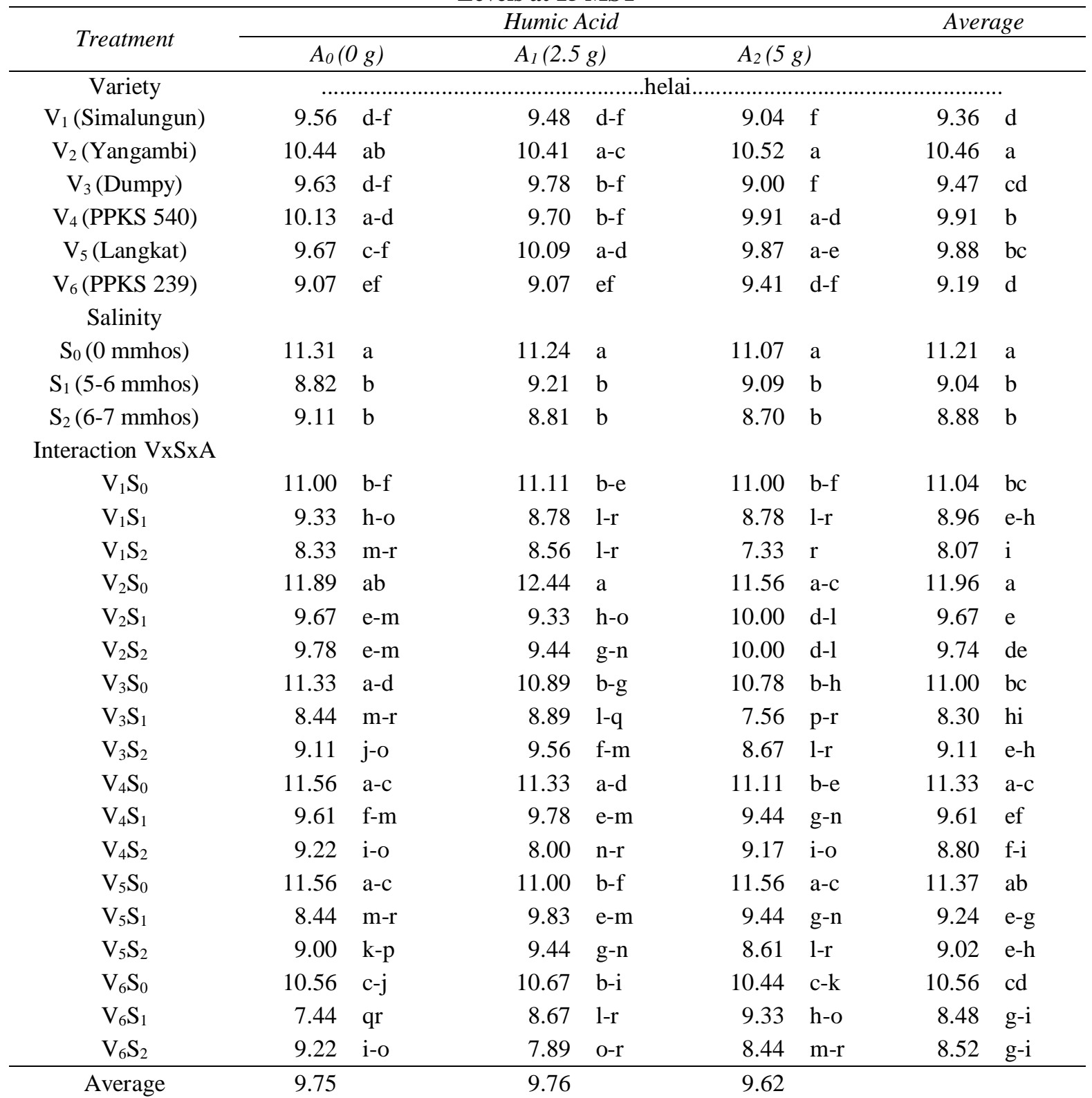

Note : The numbers followed by the same letter on the same row or column is not different significant according to Duncan Multiple Range Test at 5\% level

The result of observation of intervariety on Simalungun can be seen that the highest leaf number parameter in combination of treatment $\mathrm{V}_{1} \mathrm{~S}_{0} \mathrm{~A}_{1}$ and lowest $\mathrm{V}_{1} \mathrm{~S}_{2} \mathrm{~A}_{2}$. Yangambi highest yield on the combination of $\mathrm{V}_{2} \mathrm{~S}_{0} \mathrm{~A}_{1}$ and the lowest on $\mathrm{V}_{2} \mathrm{~S}_{1} \mathrm{~A}_{1}$. Dumpy was the highest yield on the combination of $\mathrm{V}_{3} \mathrm{~S}_{0} \mathrm{~A}_{0}$ and the lowest was obtained on $\mathrm{V}_{3} \mathrm{~S}_{1} \mathrm{~A}_{2}$. PPKS 540 yield the highest combination of $\mathrm{V}_{4} \mathrm{~S}_{0} \mathrm{~A}_{0}$ treatment and the lowest on $\mathrm{V}_{4} \mathrm{~S}_{2} \mathrm{~A}_{1}$. Langkat for the highest yield of the highest plant on the combination of $\mathrm{V}_{5} \mathrm{~S}_{0} \mathrm{~A}_{2}$ and the lowest obtained in combination $\mathrm{V}_{5} \mathrm{~S}_{1} \mathrm{~A}_{0}$. While for PPKS 239 the highest yield on the combination of $\mathrm{V}_{6} \mathrm{~S}_{0} \mathrm{~A}_{1}$ treatment and the lowest in combination $\mathrm{V}_{6} \mathrm{~S}_{1} \mathrm{~A}_{0}$.

The highest number of leaves at the 5-6 mmhos salinity level was found in $\mathrm{V}_{2} \mathrm{~S}_{1} \mathrm{~A}_{2}$ (Yangambi $+5-6$ mmhos $+5 \mathrm{~g}$ humic acid) i.e. 10.00 strands and the lowest on $\mathrm{V}_{6} \mathrm{~S}_{1} \mathrm{~A}_{0}$ (PPKS $239+5-6$ mmhos $+0 \mathrm{~g}$ humic acid) i.e. 7.44 strands. While the highest number of leaves at the salinity level of 6-7 mmhos is found in $\mathrm{V}_{2} \mathrm{~S}_{2} \mathrm{~A}_{2}$ (Yangambi + 6-7 mmhos $+5 \mathrm{~g}$ humic acid) i.e. 10.00 strands and the lowest in $\mathrm{V}_{1} \mathrm{~S}_{2} \mathrm{~A}_{2}$ (Simalungun $+6-7$ mmhos $+5 \mathrm{~g}$ humic acid) i.e. 7.33 strands. 
In salinity conditions the plants will experience water shortages due to unbalanced osmotic pressure on the soil and impact on the plant. Furthermore, nutrient deficiency occurs because nutrients can not be transported by water. Absorption of water and nutrients is absorbed by the tips of the roots. Large water and nutrient uptake causes root development, resulting in a balance of root volume with plant growth. Low amount of water will cause limited root development, thus interfering with nutrient uptake by plant roots. Drought stress will result in a low rate of water absorption by plant roots. The imbalance between water absorption by the roots and water loss due to transpiration makes plants wither. Plants may experience water deficits under certain environmental conditions. Water deficit means a decrease in the potential gradient of water between the soil, the roots, the leaves, and the atmosphere, so that the water and nutrient transport rates decrease (Taiz \& Zeiger. 2002).

The result showed that the varieties, salinity and dose of humic acid had significant effect on leaf number at 15 MST. On observation of leaf count, giving $0 \mathrm{~g}$ humic acid and salinity 0 mmhos, Yangambi (11,89 strands), Dumpy (11,33 strands), PPKS 540 (11,56 strands) and Langkat (11,56 strands) increase the number of oil palm leaves. While the combination of poor treatment is $\mathrm{V}_{1} \mathrm{~S}_{2} \mathrm{~A}_{2}(7,33)$. This is allegedly closely related to the genetic factors of plants, which in certain phases of plants show or show different appearance with other plants according to their respective varieties. Specific plant growth patterns depend on the genetic and environmental variations that affect them [13]. The higher the dose of humic acid, the lower the number of leaves produced. This can be seen in $\mathrm{V}_{1} \mathrm{~S}_{2} \mathrm{~A}_{1}$ $(8,56)$ decreasing on $\mathrm{V}_{1} \mathrm{~S}_{2} \mathrm{~A}_{2}(7,33)$. The use of humic acid with high concentration can interfere with plant growth. The main effect of salinity is the decrease in leaf growth that directly leads to reduced plant photosynthesis. Salinity reduces growth and crop yields are important and in the worst conditions can lead to crop failure. In saline conditions, growth and development of plants are inhibited due to excessive accumulation of $\mathrm{Na}$ and $\mathrm{Cl}$ in the cytoplasm, causing changes in metabolism in cells (Lestari, 2006) (Yuniati, 2014).

\subsection{Dry root weight (g)}

The result of F-test showed that the varieties, salinity levels as well as the interaction of varieties and salinity levels significantly affected root dry weight. Different test of dry weight and root weight of several palm oil varieties with the addition of humic acid and salinity levels can be seen in Table 3.

Differences in the dosage of humic acid do not give a real response to the combination of varieties with humic acid and salinity medium with humic acid. Giving humic acid $5 \mathrm{~g}$ decreases root dry weight. Oil palm is one of the plants that are not tolerant to salinity. The harsh soil conditions and lack of water cause the plants to decrease their morphological appearance. Plants with salinity levels of 6-7 mmhos appear to be leaf-like burning conditions, the leaves are not perfectly open and the size of the dwarf. According to Fitter and Hay (1998) the state of water stress causes a decrease in turgor in plant cells and result in decreased physiological processes. Water plays an important role for plants. Water content in plants will be influenced by environmental factors, and one of them is the water content itself (Taiz \& Zeiger. 2002).

The highest root dry weight at 5-6 mmhos salinity was found in $\mathrm{V}_{3} \mathrm{~S}_{1} \mathrm{~A}_{2}$ (Dumpy $+5-6$ mmhos $+5 \mathrm{~g}$ humic acid) of $10.27 \mathrm{~g}$ and the lowest on $\mathrm{V}_{5} \mathrm{~S}_{1} \mathrm{~A}_{1}$ (Langkat 5-6 mmhos $+2.5 \mathrm{~g}$ humic acid) that is $4.17 \mathrm{~g}$. While the highest root dry weight at the salinity level of 6-7 mmhos was found in $\mathrm{V}_{2} \mathrm{~S}_{2} \mathrm{~A}_{2}$ (Yangambi $+6-7$ mmhos $+5 \mathrm{~g}$ humic acid) of $7.93 \mathrm{~g}$ and the lowest on $\mathrm{V}_{4} \mathrm{~S}_{2} \mathrm{~A}_{1}$ (PPKS $540+6-7$ mmhos $+2.5 \mathrm{~g}$ humic acid) is $4.40 \mathrm{~g}$.

Table 3. Dry Root Weight (g) Several Palm Oil Varieties with Addition of Humic Acid and Salinity Content

\begin{tabular}{|c|c|c|c|c|c|}
\hline \multirow{2}{*}{ Treatment } & \multicolumn{3}{|c|}{ Humic Acid } & \multirow{2}{*}{\multicolumn{2}{|c|}{ Average }} \\
\hline & $A_{0}(0 g)$ & $A_{l}(2.5 \mathrm{~g})$ & $A_{2}(5 g)$ & & \\
\hline Variety & & & & & \\
\hline $\mathrm{V}_{1}$ (Simalungun) & 6.98 & 6.98 & 6.79 & 6.91 & $\mathrm{~b}$ \\
\hline $\mathrm{V}_{2}($ Yangambi) & 9.62 & 10.42 & 8.83 & 9.63 & $\mathrm{a}$ \\
\hline $\mathrm{V}_{3}$ (Dumpy) & 5.53 & 6.24 & 7.59 & 6.46 & $\mathrm{~b}$ \\
\hline $\mathrm{V}_{4}(\mathrm{PPKS} 540)$ & 9.03 & 6.56 & 6.61 & 7.40 & $\mathrm{~b}$ \\
\hline $\mathrm{V}_{5}$ (Langkat) & 7.30 & 6.18 & 6.93 & 6.80 & $\mathrm{~b}$ \\
\hline $\mathrm{V}_{6}(\mathrm{PPKS} 239)$ & 5.74 & 6.43 & 6.33 & 6.17 & $\mathrm{~b}$ \\
\hline \multicolumn{6}{|l|}{ Salinity } \\
\hline $\mathrm{S}_{0}(0 \mathrm{mmhos})$ & 10.00 & 9.66 & 8.57 & 9.41 & $\mathrm{a}$ \\
\hline $\mathrm{S}_{1}(5-6 \mathrm{mmhos})$ & 6.60 & 5.96 & 6.70 & 6.42 & $\mathrm{~b}$ \\
\hline $\mathrm{S}_{2}(6-7 \mathrm{mmhos})$ & 5.51 & 5.78 & 6.28 & 5.86 & $\mathrm{~b}$ \\
\hline \multicolumn{6}{|l|}{ Interaction $\mathrm{VxSxA}$} \\
\hline $\mathrm{V}_{1} \mathrm{~S}_{0}$ & 9.23 & 7.83 & 8.23 & 8.43 & $\mathrm{~cd}$ \\
\hline $\mathrm{V}_{1} \mathrm{~S}_{1}$ & 6.73 & 7.20 & 5.97 & 6.63 & d-g \\
\hline
\end{tabular}




\begin{tabular}{ccccrl}
$\mathrm{V}_{1} \mathrm{~S}_{2}$ & 4.97 & 5.90 & 6.17 & 5.68 & $\mathrm{~d}-\mathrm{g}$ \\
$\mathrm{V}_{2} \mathrm{~S}_{0}$ & 11.83 & 17.30 & 10.57 & 13.23 & $\mathrm{a}$ \\
$\mathrm{V}_{2} \mathrm{~S}_{1}$ & 8.70 & 7.10 & 8.00 & 7.93 & $\mathrm{c}-\mathrm{e}$ \\
$\mathrm{V}_{2} \mathrm{~S}_{2}$ & 8.33 & 6.87 & 7.93 & 7.71 & $\mathrm{c}-\mathrm{f}$ \\
$\mathrm{V}_{3} \mathrm{~S}_{0}$ & 6.23 & 6.07 & 5.90 & 6.07 & $\mathrm{~d}-\mathrm{g}$ \\
$\mathrm{V}_{3} \mathrm{~S}_{1}$ & 5.63 & 6.43 & 10.27 & 7.44 & $\mathrm{c}-\mathrm{f}$ \\
$\mathrm{V}_{3} \mathrm{~S}_{2}$ & 4.73 & 6.23 & 6.60 & 5.86 & $\mathrm{e}-\mathrm{g}$ \\
$\mathrm{V}_{4} \mathrm{~S}_{0}$ & 13.93 & 10.27 & 9.47 & 11.22 & $\mathrm{ab}$ \\
$\mathrm{V}_{4} \mathrm{~S}_{1}$ & 7.57 & 5.00 & 5.43 & 6.00 & $\mathrm{~d}-\mathrm{g}$ \\
$\mathrm{V}_{4} \mathrm{~S}_{2}$ & 5.60 & 4.40 & 4.93 & 4.98 & $\mathrm{fg}$ \\
$\mathrm{V}_{5} \mathrm{~S}_{0}$ & 12.03 & 7.80 & 8.90 & 9.58 & $\mathrm{bc}$ \\
$\mathrm{V}_{5} \mathrm{~S}_{1}$ & 3.90 & 4.17 & 4.93 & 4.33 & $\mathrm{~g}$ \\
$\mathrm{~V}_{5} \mathrm{~S}_{2}$ & 5.97 & 6.57 & 6.97 & 6.50 & $\mathrm{~d}-\mathrm{g}$ \\
$\mathrm{V}_{6} \mathrm{~S}_{0}$ & 6.73 & 8.70 & 8.33 & 7.92 & $\mathrm{c}-\mathrm{e}$ \\
$\mathrm{V}_{6} \mathrm{~S}_{1}$ & 7.07 & 5.87 & 5.60 & 6.18 & $\mathrm{~d}-\mathrm{g}$ \\
$\mathrm{V}_{6} \mathrm{~S}_{2}$ & 3.43 & 4.73 & 5.07 & 4.41 & $\mathrm{~g}$ \\
\hline Average & 7.37 & 7.14 & 7.18 & & \\
\hline
\end{tabular}

Note : The numbers followed by the same letter on the same row or column is not different significant according to Duncan Multiple Range Test at 5\% level

From the average of Table 3 it can be seen that $\mathrm{V}_{2} \mathrm{~S}_{0}$ (Yangambi +0 mmhos) that is $13.23 \mathrm{~g}$ is not significantly different with $\mathrm{V}_{4} \mathrm{~S}_{0}$ (PPKS $540+0$ mmhos) i.e. $11.22 \mathrm{~g}$. This shows that salinity level $\mathrm{S}_{0}$ has the best ability to increase the dry weight of the root of oil palm. On observation of root dry weight, $V_{2} S_{0}$ (Yangambi +0 mmhos) that is $13.23 \mathrm{~g}$ is not significantly different with $\mathrm{V}_{4} \mathrm{~S}_{0}$ (PPKS $540+0 \mathrm{mmhos}$ ) that is $11.22 \mathrm{~g}$. This shows that Yangambi and PPKS 540 varieties are the best varieties at salinity level $\mathrm{S}_{0}(0 \mathrm{mmhos})$. The root dry weight of the $\mathrm{S}_{0}(0$ mmhos) treatment was higher than the $S_{1}$ treatment $\left(5-6\right.$ mmhos) and $S_{2}\left(6-7\right.$ mmhos). At the $S_{0}$ treatment, the roots appear dense and indicate the oil palm is able to bind energy and nutrients from the soil. In $S_{1}$ and $S_{2}$ treatments, the roots are longer due to the harsh soil conditions and nutrient limitations causing the roots to seek sources of energy and nutrients to a deeper place. The accumulation of dry matter such as plant weight reflects the ability of plants to bind energy from sunlight through photosynthesis, and their interaction with environmental factors. The distribution of this dry matter accumulation shows the productivity of the plant (Fried \& Hademenos, 2005).

Observation result of intervariety on Simalungun can be seen that the highest root dry weight parameter in combination of treatment $V_{1} S_{0} A_{1}$ and lowest $V_{1} S_{2} A_{0}$. Yangambi yields the highest yield on the combination of $V_{2} S_{0} A_{1}$ and the lowest on $V_{2} S_{1} A_{0}$. Dumpy of highest yield on combination of $V_{3} S_{0} A_{2}$ and lowest treatment were obtained on $\mathrm{V}_{3} \mathrm{~S}_{1} \mathrm{~A}_{1}$. PPKS 540 yield the highest combination of $\mathrm{V}_{4} \mathrm{~S}_{0} \mathrm{~A}_{0}$ treatment and the lowest on $\mathrm{V}_{4} \mathrm{~S}_{1} \mathrm{~A}_{1}$. Langkat for the highest yield of the highest plant on the combination of $\mathrm{V}_{5} \mathrm{~S}_{0} \mathrm{~A}_{2}$ and the lowest obtained in combination $\mathrm{V}_{5} \mathrm{~S}_{1} \mathrm{~A}_{0}$. While for PPKS 239 the highest result in the combination of $\mathrm{V}_{6} \mathrm{~S}_{0} \mathrm{~A}_{0}$ treatment and the lowest in combination $\mathrm{V}_{6} \mathrm{~S}_{2} \mathrm{~A}_{1}$.

The presence of water on the soil is necessary. Palm oil roots harvested at 5-6 and 6-7 mmhos salinity treatments appear to be longer than palm oil harvested in the treatment of salinity $0 \mathrm{mmhos}$. The availability of water greatly affects the growth of plant height and the development of meristem tissues at the point of plant growth. When plants lack water then plants can not grow properly (Harjadi, 2002).

\subsection{Root volume ( $\mathrm{ml})$}

Based on the result of $\mathrm{F}$ test indicated that varieties and salinity levels significantly affected the root volume. Test the difference of the average and the root volume of several varieties of oil palm with the addition of humic acid and salinity levels can be seen in Table 4.

The treatment Yangambi $(46,11 \mathrm{ml})$ showed significantly different with other varieties. While salinity treatment showed no significant difference between salinity 5-6 mmhos with 6-7 mmhos. Interaction of humic acid with the highest salinity for root volume parameters i.e. salinity 0 mmhos with humic acid administration. This shows that the administration of humic acid has not been able to improve salinity.

The interaction of varieties, salinity and humic acid has no significant effect on root volume. Observation of Simalungun intervariety highest root volume in combination of $\mathrm{V}_{1} \mathrm{~S}_{0} \mathrm{~A}_{2}$ treatment and lowest $\mathrm{V}_{1} \mathrm{~S}_{0} \mathrm{~A}_{0}$. Yangambi is the highest yield on the combination of $\mathrm{V}_{2} \mathrm{~S}_{0} \mathrm{~A}_{0}$ and the lowest on $\mathrm{V}_{2} \mathrm{~S}_{2} \mathrm{~A}_{1}$. Dumpy yield the highest average on 
combination of $\mathrm{V}_{3} \mathrm{~S}_{1} \mathrm{~A}_{2}$ and lowest $\mathrm{V}_{3} \mathrm{~S}_{2} \mathrm{~A}_{1}$. The PPKS 540 contributed the highest on the combination of $\mathrm{V}_{4} \mathrm{~S}_{0} \mathrm{~A}_{0}$ treatment and the lowest on $\mathrm{V}_{4} \mathrm{~S}_{1} \mathrm{~A}_{1}$ and $\mathrm{V}_{4} \mathrm{~S}_{2} \mathrm{~A}_{1}$. Langkat highest yield on combination of $\mathrm{V}_{5} \mathrm{~S}_{0} \mathrm{~A}_{2}$ and lowest combination of $V_{5} S_{1} A_{2}$. While the combination of treatment $V_{6} S_{0} A_{1}$ is the highest average and $V_{6} S_{2} A_{2}$ is the result of the lowest average root volume. This suggests that all varieties grown on the salinity medium have decreased root volume despite being given humic acid.

At a salinity level of 5-6 mmhos, the highest root volume was found in $\mathrm{V}_{2} \mathrm{~S}_{1} \mathrm{~A}_{1}$ (Yangambi $+5-6$ mmhos $+2.5 \mathrm{~g}$ humic acid) of $46.67 \mathrm{ml}$ and the lowest was in $\mathrm{V}_{5} \mathrm{~S}_{1} \mathrm{~A}_{2}$ (Langkat $+5-6$ mmhos $+5 \mathrm{~g}$ humic acid) is $20.67 \mathrm{ml}$. At a salinity level of 6-7 mmhos, the highest root volume was found in $\mathrm{V}_{2} \mathrm{~S}_{2} \mathrm{~A}_{0}$ (Yangambi $+6-7$ mmhos $+0 \mathrm{~g}$ humic acid) of $43.33 \mathrm{ml}$ and the lowest was on $\mathrm{V}_{4} \mathrm{~S}_{2} \mathrm{~A}_{1}$ (PPKS $540+6-7$ mmhos $+2.5 \mathrm{~g}$ humic acid) that is $21.67 \mathrm{ml}$.

Table 4. Root Volume (ml) Some Varieties of Oil Palm with Addition of Humic Acid and Salinity Content

\begin{tabular}{|c|c|c|c|c|c|}
\hline \multirow{2}{*}{ Treatment } & \multicolumn{3}{|c|}{ Humic Acid } & \multirow{2}{*}{\multicolumn{2}{|c|}{ Average }} \\
\hline & $A_{0}(O g)$ & $A_{l}(2.5 \mathrm{~g})$ & $A_{2}(5 g)$ & & \\
\hline Variety & \multicolumn{3}{|c|}{..................ml } & & \\
\hline $\mathrm{V}_{1}$ (Simalungun) & 32.22 & 31.11 & 39.44 & 34.26 & $\mathrm{~b}$ \\
\hline $\mathrm{V}_{2}$ (Yangambi) & 48.33 & 46.11 & 43.89 & 46.11 & $\mathrm{a}$ \\
\hline $\mathrm{V}_{3}$ (Dumpy) & 30.56 & 30.56 & 32.78 & 31.30 & $\mathrm{~b}$ \\
\hline $\mathrm{V}_{4}(\mathrm{PPKS} 540)$ & 43.33 & 26.11 & 30.78 & 33.41 & $\mathrm{~b}$ \\
\hline $\mathrm{V}_{5}$ (Langkat) & 35.56 & 33.89 & 31.33 & 33.59 & $\mathrm{~b}$ \\
\hline $\mathrm{V}_{6}(\mathrm{PPKS} 239)$ & 29.44 & 33.33 & 27.78 & 30.19 & $\mathrm{~b}$ \\
\hline \multicolumn{6}{|l|}{ Salinity } \\
\hline $\mathrm{S}_{0}(0 \mathrm{mmhos})$ & 44.44 & 40.56 & 40.28 & 41.76 & $\mathrm{a}$ \\
\hline $\mathrm{S}_{1}(5-6 \mathrm{mmhos})$ & 32.78 & 30.83 & 33.72 & 32.44 & $\mathrm{~b}$ \\
\hline$S_{2}(6-7$ mmhos $)$ & 32.50 & 29.17 & 29.00 & 30.22 & $\mathrm{~b}$ \\
\hline \multicolumn{6}{|l|}{ Interaction $\mathrm{VxSxA}$} \\
\hline $\mathrm{V}_{1} \mathrm{~S}_{0}$ & 40.00 & 31.67 & 48.33 & 40.00 & \\
\hline $\mathrm{V}_{1} \mathrm{~S}_{1}$ & 30.00 & 30.00 & 43.33 & 34.44 & \\
\hline $\mathrm{V}_{1} \mathrm{~S}_{2}$ & 26.67 & 31.67 & 26.67 & 28.33 & \\
\hline $\mathrm{V}_{2} \mathrm{~S}_{0}$ & 61.67 & 55.00 & 45.00 & 53.89 & \\
\hline $\mathrm{V}_{2} \mathrm{~S}_{1}$ & 40.00 & 46.67 & 43.33 & 43.33 & \\
\hline $\mathrm{V}_{2} \mathrm{~S}_{2}$ & 43.33 & 36.67 & 43.33 & 41.11 & \\
\hline $\mathrm{V}_{3} \mathrm{~S}_{0}$ & 28.33 & 33.33 & 33.33 & 31.67 & \\
\hline $\mathrm{V}_{3} \mathrm{~S}_{1}$ & 36.67 & 33.33 & 36.67 & 35.56 & \\
\hline $\mathrm{V}_{3} \mathrm{~S}_{2}$ & 26.67 & 25.00 & 28.33 & 26.67 & \\
\hline $\mathrm{V}_{4} \mathrm{~S}_{0}$ & 61.67 & 35.00 & 36.67 & 44.44 & \\
\hline $\mathrm{V}_{4} \mathrm{~S}_{1}$ & 38.33 & 21.67 & 33.33 & 31.11 & \\
\hline $\mathrm{V}_{4} \mathrm{~S}_{2}$ & 30.00 & 21.67 & 22.33 & 24.67 & \\
\hline $\mathrm{V}_{5} \mathrm{~S}_{0}$ & 43.33 & 41.67 & 45.00 & 43.33 & \\
\hline $\mathrm{V}_{5} \mathrm{~S}_{1}$ & 25.00 & 30.00 & 20.67 & 25.22 & \\
\hline $\mathrm{V}_{5} \mathrm{~S}_{2}$ & 38.33 & 30.00 & 28.33 & 32.22 & \\
\hline $\mathrm{V}_{6} \mathrm{~S}_{0}$ & 31.67 & 46.67 & 33.33 & 37.22 & \\
\hline $\mathrm{V}_{6} \mathrm{~S}_{1}$ & 26.67 & 23.33 & 25.00 & 25.00 & \\
\hline $\mathrm{V}_{6} \mathrm{~S}_{2}$ & 30.00 & 30.00 & 25.00 & 28.33 & \\
\hline Average & 36.57 & 33.52 & 34.33 & & \\
\hline
\end{tabular}

Note: The numbers followed by the same letter on the same row or column is not different significant according to Duncan Multiple Range Test at 5\% level

Provision of humic acid is expected to improve soil structure so that soil microorganisms are more easily developed and the physical and biological properties of the soil are better, drainage and aerase are maintained, closely related to the growth process and lead to better growing space for root development, which will affect the process nutrient uptake in the soil. The availability of nutrients absorbed by plants is one factor that can affect the growth of plants so that the morphology of plants increases (Sarief, 1985).

In observation of root volume, $\mathrm{S} 0(0 \mathrm{mmhos})$ that is $41,76 \mathrm{ml}$ significantly different with $\mathrm{S} 1$ (5-6 mmhos) that is $32,44 \mathrm{ml}$ and $\mathrm{S} 2$ (6-7 mmhos) that is $30,22 \mathrm{ml}$. This suggests that salinity of S1 (5-6 mmhos) and S2 (6-7 mmhos) 
limits the growth of palm oil root volume. Salinity potentially inhibits root growth, root osmotic adjustment, root pressure, sodium ion expenditure and water extraction [16].

\section{CONCLUSIONS}

The varieties used showed different resistance to salinity level of planting media which was shown through decreasing observation result parameters such as plant height, number of leaves and root volume. Application humic acid $5 \mathrm{~g}$ on saline soil 6-7 mmhos able to improve physical condition of saline soil. Under the conditions of S1 (5-6 mmhos) and S2 (6-7 mmhos), Yangambi varieties are able to maintain the morphology of oil palm. The interaction between Yangambi varieties with application of humic acid $5 \mathrm{~g}$ on saline soil 5-6 mmhos can increase oil palm plant height, number of leaves, root dry weight and root volume.

\section{REFERENCES}

Pardamean, M. 2008. Complete Guide of Management of Oil Palm Plantation and Plant. First Edition. Agromedia Pustaka. Jakarta. 226 hal.

Directorate General of Estate Crops. 2015. Strategic Plan of Directorate General of Estate Crops 2015-2019. Jakarta.

Slinger, D. and Tenison, K. 2005. Salinity Glove Box Guide - NSW Murray and Murrumbidgee Catchments. An initiative of the Southern Salt Action Team, NSW Department of Primary Industries.

Harjadi, S.S and S. Yahya. 1988. Plant Stress Physiology. PAU IPB, Bogor.

Tan, K.H. 2000. Environmental Soil Science. Marcel Dekker, New York.

Santi, L. P. 2015, Effect of Humic Acid on Cocoa Seed Growth (Theobroma cacao) and Population of Microorganisms in the Soil Humic Dystrudept. PT. Research of Nusantara Plantation, Bogor.

Abdel M., A, El Greadly M. R. N., Helmy, Y. I. and Singer, S. M. 2007. Responses of Tomato Plants to Different Rates of Humic Based Fertilizer and NPK Fertilization. J. of Applied Sciences Research 3:169-174.

Welsh, J. R. 1981. Genetic and Plant Breeding. Translated by Johanis P. Mogea from Fundamental of Plant Genetic and Breeding. Erlangga, Jakarta. p 224.

Sitompul, S. M. and Guritno, B. 1995. Plant Growth Analysis. Gadjahmada University Press, Yogyakarta.

Lestari, A. 2006. Study of Acid Utilization Result of Extraction from Andosol and Peat in Rice Paddle Growth. Soil Science Program, Faculty of Agriculture Bogor. Bogor.

Yuniati, R. 2004. Soy Barrack (Glycine max (L.) Merill) Tolerance Against $\mathrm{NaCl}$ for Planting in Saline Soil. Makarah 8 (1): 21-24.

Taiz, L. and E. Zeiger. 2002. Plant Physiology. Third Edition. Massachusetts: Sinauer Associate Inc. Publisher Sunderland. $667 \mathrm{p}$.

Fried, G.H. and Hademenos, G.J. 2005. Biology. Second Edition. PT. Gelora Aksara Pratama, Jakarta.

Harjadi, S.S.M.M. 2002. Introduction of Agronomy. Gramedia Pustaka Utama, Jakarta.

Sarief, S. 1985. Soil and Water and Conservation. Pustaka Buana, Bandung.

An, P., S. Inanaga, Y. Cohen, U. Kafkafi and Y. Sugimoto. 2002. Salt Tolerance In Two Soybean Cultivars. J.Plant. 